\title{
INVESTIGATION IN SELECTING THE OPTIMUM AIRPORT RUNWAY ORIENTATION WITH SPECIAL REFERENCE TO EGYPTIAN AIRPORTS
}

\section{El-Sayed Mohamed Abdalla, Mahmoud Enieb Osman, and Ramy Nasr Abd El-monem Mohamed}

Civil Engineering Department, Faculty of Engineering, Assiut University

(Received August 16, 2011 Accepted September 20, 2011)

Determination of a runway orientation is a critical task in the planning and design of an airport. Runways usually oriented in the direction of the prevailing winds. The best direction can be decided through proper execution of wind analysis for designated area. In this study, wind analysis is conducted by manual analysis and computer analysis to check the accuracy of used software in computer analysis by comparing their results with the manual procedure. The manual analysis represented by windrose type II while the computer analysis represented by two software FAA Airport design and Windrose PRO. In order to analyze the available local wind observations with windrose II manual procedure and FAA Airport design software they must be converted to suitable windrose statistics so that a third software should be used . In this study WRPLOT View software is used to do this task. In this study three case studies Aswan international airport, Al Nozha international airport and Marsa Alam international airport were studied. These cases studies subject to wind analysis by use of manual analysis and computer analysis. For FAA Airport Design and WindRose PRO software there were small differences between its results and windrose II manual analysis results. In order to verify the optimization process in each case study, a comparison was made between existing runways orientation and estimated optimum runways orientation. For Aswan international airport the existing runway which has actual orientation of 170.88/350.88 which provides $98.07 \%$ wind coverage while the optimum runway orientation is $174 / 354$ which provides $98.2 \%$ wind coverage. For Al Nozha there are two existing runways which have actual orientation of 45.06/225.07 and 179.99/359.99 which provides $84.11 \%$ and $93.27 \%$ wind coverage respectively while the optimum runway orientation is one runway with orientation of 146/326 which provides $96.04 \%$ wind coverage. For Marsa Alam international airport the existing runway which has actual orientation of 149.75/329.76 which provides $99.65 \%$ wind coverage while the optimum runway orientation is 156/336 which provides $99.72 \%$ wind coverage. Parametric analysis applied on each case study in order to studying the effect of each controlling parameter on wind coverage. This analysis is proceed by use of FAA Airport Design software because it allow the designer to keep the other parameters fixed while changing one of them. These parameters are number of runways, runway orientation, maximum allowable crosswind component and maximum allowable tailwind component. 


\section{INTRODUCTION}

The runway requirements are dimensional criteria, orientation, length, width and pavement design strength. The direction of the runway controls the layout of the other airport facilities, such as passenger terminals, taxiways/apron configurations, circulation roads, and parking facilities. Very often runway orientation is an important task in the assessment of an airport site. The wind conditions are the most critical and safety-alarming elements that challenge airport planners and designers in the determination of runway orientation for a chosen airport site. An accurate analysis of wind is essential to determine the orientation and number of runways in any airport in order to give the desired wind coverage depending on the planed airport and its related maximum allowable crosswind [1], [2].

\section{OBJECTIVES AND IMPORTANCE OF THE STUDY}

The main objective of this study is to conduct wind analysis using local wind data provided by Egyptian meteorological organization and Synop reports in three major cities in Egyptian where existing airports are available. These analyses are conducted once through the use of windRose II technique, second by use of FAA Airport Design program and third by use of WindRose PRO program. Then several results are going to be compared and verified as following:-

1- To compare between the results of the manual wind analysis results calculated by the use of windRose II technique with FAA Airport Design program results and WindRose PRO program results to investigate each program capability of selecting optimum airport runway orientation.

2- Conducting operational analysis to the existing runways systems in local cases studies by calculating wind coverage of their orientation.

3- To conduct parametric study for each local case study.

\section{METHODOLOGY}

In order to achieve the objectives of this study some steps were conducted in this study as shown in Figure 1.

\section{RUNWAY ORIENTATION}

Desirable runway orientation based on wind direction, crosswind wind component and wind coverage. Runway is always oriented in the direction of prevailing wind. When landing and taking off aircraft are able to maneuver on a runway, the aircraft will subject to crosswind component as shown in figure 2. For safety of the maneuver operation the runway should be oriented to have the largest wind coverage and minimum cross wind component. The head wind opposite to the direction of landing and takeoff provides greater lift on the wings of the aircraft when it taking off that making the aircraft raises above the ground much earlier requiring short length of the runway. During landing the headwind provides a breaking effect due to the drag developed by friction between aircraft fuselage and the air [2], [3], [4]. 


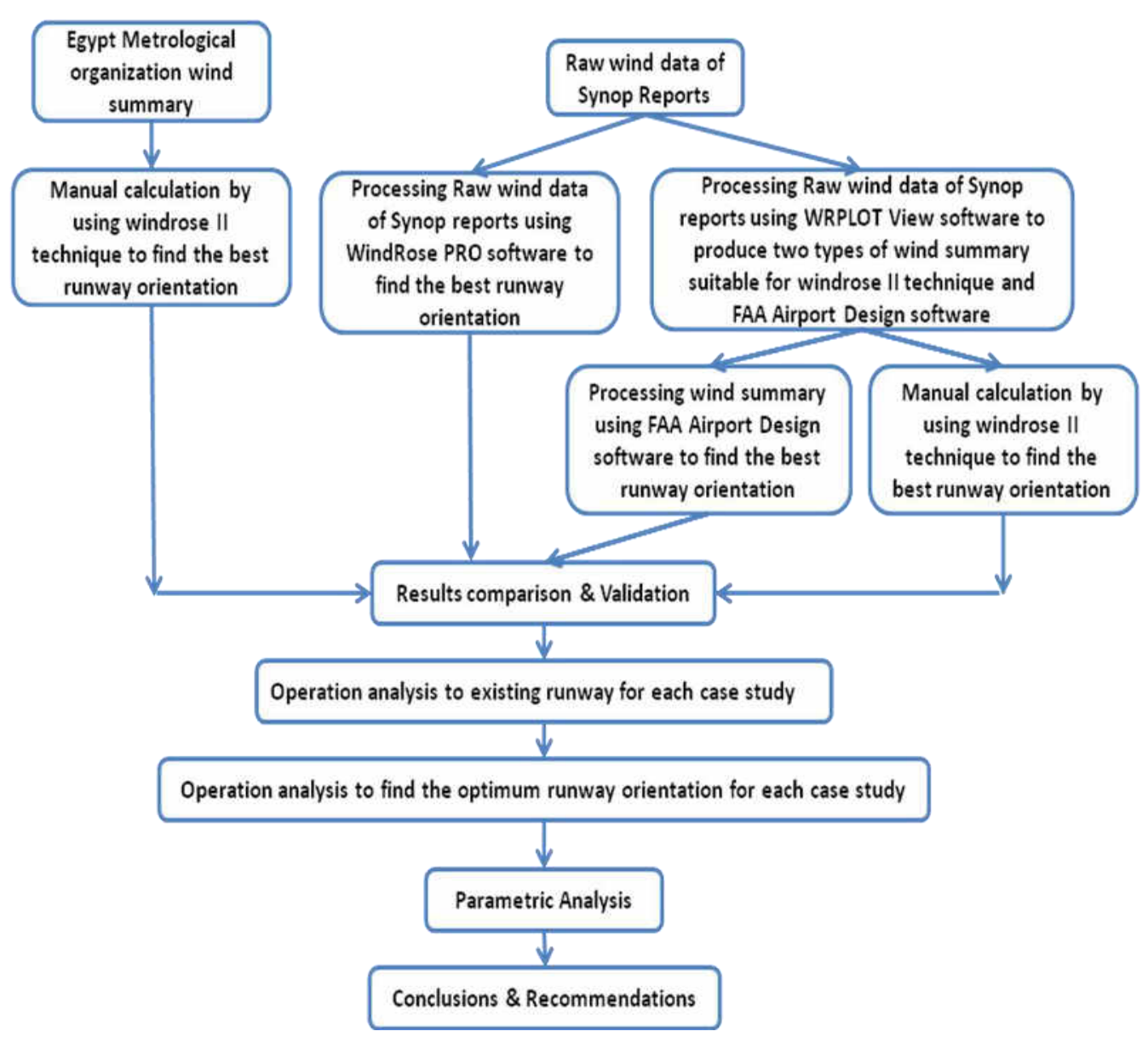

Figure 1. Research structure diagram.

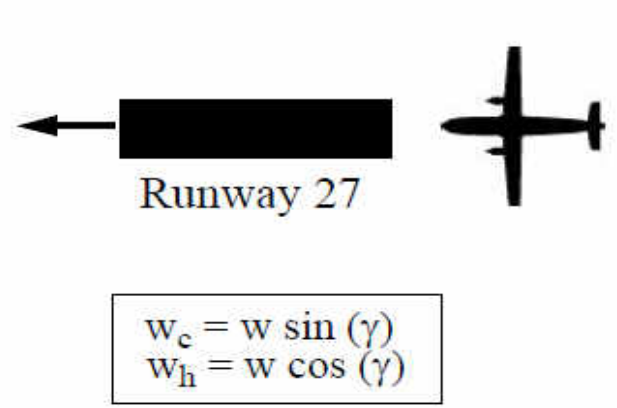

NOTE: Winds are always reported with respect to the magnetic North (in ATC transmissions)
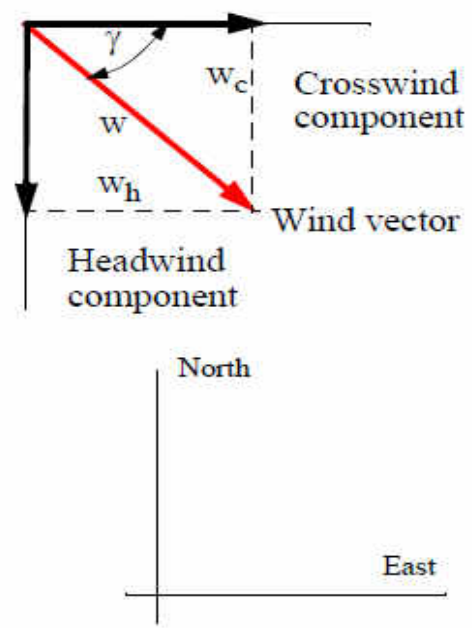

Figure 2. Cross wind component. 


\subsection{Wind Characteristics}

Wind is a factor influencing runway orientation and numbers of runways. Airport planners and designers should make an accurate analysis of wind to determine the orientation and number of runways. The results of this analysis will add substantially to the safety and usefulness of the airport. The most desirable direction of runways can be determined by examination of the wind characteristics for the following conditions Cross wind, Wind coverage, Tailwind, Headwind, Gusting winds, Turbulence and wind shear. Crosswind and wind coverage are the most important wind factors affect the optimum runway orientation [1], [2], [3], [4].

\subsubsection{Crosswind}

A crosswind is any wind that is blowing perpendicular to a line of travel, or perpendicular to a direction. In aviation, a crosswind is the component of wind that is blowing across the runway making a landing more difficult than if the wind were blowing straight down the runway. If a crosswind is strong enough it may exceed an aircraft's crosswind limit and an attempt to land under such conditions could cause structural damage to the aircraft's undercarriage. When winds are neither perpendicular nor parallel to the line of travel, the wind is said to have a crosswind component; that is can be separated into two components, a crosswind component and a headwind or tailwind component. The crosswind component is computed by multiplying the wind speed by the sine of the angle between the wind and the direction of travel as shown in Figure 2. The Federal Aviation Administration (FAA) and the International Civil Aviation Organization (ICAO) has established their design standards that recommend a runway in the direction of prevailing winds. According to FAA \& ICAO standards, runways should be oriented so that aircraft can takeoff and/or land at least 95\% of the time without exceeding the allowable crosswinds [1], [2], [3], [4], [5], [6].

\subsubsection{Wind Coverage}

The most desirable runway orientation is the one which has the largest wind coverage and minimum crosswind components. Wind coverage is that percent of time crosswind components below an acceptable velocity. The desirable wind coverage for an airport is 95 percent based on the total number of weather observations. This value of 95 percent takes into account various factors influencing operations and the economics of providing the coverage [3].

\subsection{Wind Data}

In order to carry out proper wind analysis the latest and best wind information should always be used. A record which covers the last 10 consecutive years of wind observation is preferred. Wind data records usually consist of observations taken regularly every hour. Each observation includes apart from wind speed and direction, the cloud and visibility, air temperature and pressure. Wind data are usually collected and processed in many ways according to their needs. Generally they are classified according to the direction and speed [1], [2], [3], [4]. 


\subsubsection{SYNOP Reports}

SYNOP (surface synoptic observations) is a numerical code used for reporting weather observations made by manual and automated weather stations. A report consists of groups of numbers describing general weather information, such as the temperature, barometric pressure, wind directions, wind speed and visibility at a weather station. These reports were used to prepare wind statistics for each case study [7], [8], [9].

\subsubsection{Analyzing Wind Data}

Wind information could be analyzed in many ways, either manually or by using computer programs. The manual procedure which uses a graphical presentation of this information consists of two main types of windrose. While on the other hand, the computer programs include many programs capable of analyzing wind to drawing windrose and examining wind data to find the optimum runway orientation like WRPLOT View software, FAA airport design software and Wind Rose PRO software [1], [2], [3], [10], [11], [12].

\subsubsection{Wind Rose Diagram}

This is a graphical procedure used to analyze the wind data for the determination of the best runway orientation. The wind data on its velocity, directions, duration or frequency are represented by a diagram called 'wind rose' as shown in figure 4. A wind analysis should be based on reliable wind distribution statistics for a period of 5 to 10 years. In the estimation of best runway orientation there are two methods to analyses the wind data through wind rose diagram. The first method (windrose I) is not accurate, hence is only a rough guide. The second method (windrose II) is accurate and compatible to select runway orientation [1], [2], [3].

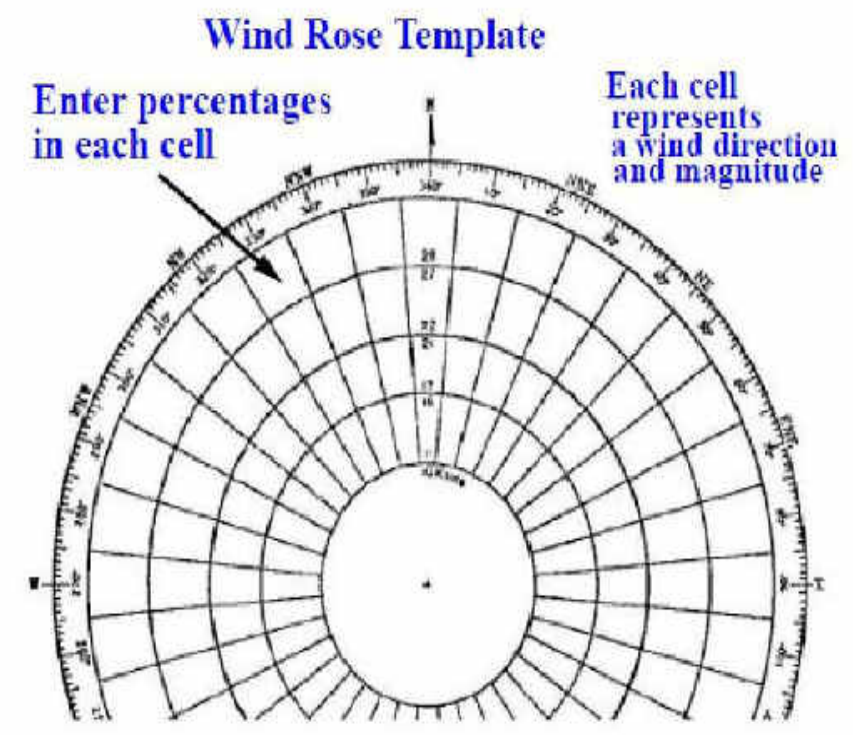

Figure 4. Windrose diagram. 


\subsubsection{WRPLOT View Software}

WRPLOT View software comes from a company called Lakes Environmental that specializes in tools for studying air pollution. WRPLOT View developed to produce graphic plots of wind rose and windrose Statistics. A wind rose depicts the frequency of occurrence of winds in user defined sectors (wind directions) of $4,6,8,10,12,16,18,20,24,36$ directions and user defined wind speed classes from 1 class to 9 classes as for a given location and time period. [12].

\subsubsection{FAA Airport Design Software}

FAA Airport Design software is a computer program prepared by FAA with design standards to augment many FAA advisory circulars and to be provides many parameters on of each is runway wind coverage analysis. Standard wind analysis is represented by the task number 3 in the airport design program to provide the wind analysis standards provided by the FAA AC150/5300-13, Appendix 1. This task calculates the wind coverage for up to a six runway configuration. In this program four variables represent the controlling parameters they are Numbers of runways, Runway orientation, Cross wind component and Tailwind component [10].

\subsubsection{WindRose PRO Program}

Wind Rose PRO is a Windows application for representing directional variables starting from raw data or from their frequencies. It can be used to represent wind roses, but it is also possible to represent roses of directions and any other variable of interest. A wind rose depicts the frequency of occurrence of winds in each of the specified wind direction sectors and wind speed classes for a given location and time period. The wind roses can be exported in DXF format for CAD systems, in SHP format for GIS environments and in KML format for Google Earth. This program capable for Calculates crosswind, headwind and tailwind, and evaluates the correct orientation of a runway only for single runway configuration. [11].

\section{Cases Studies}

Three case studies are going to be use in this study to studding how to selecting the optimum airport runway orientation. Each of this case is represent an airport in local city. Wind observation is available for each case. The orientation of the runway for each case will be estimate according to the above listed processes. The orientation of runway of each case will depend on the studding of existing wind of this airport. The first case study is Aswan International Airport, located close to Aswan has one asphaltic runway and its actual orientation is 170.88/350.88 and its designation is 17/35. The second case study is Al Nozha International Airport that is located in Alexandria city has two asphaltic runway. The first runway has actual orientation of 45.06/225.07 and its designation is 04/22. The second runway has actual orientation of 179.99/359.99 and its designation is 18/36. The third case study is Marsa Alam International Airport that is located in Marsa Alam city has 1 asphaltic runway and its actual orientation is $149.75 / 329.76$ and its designation is $15 / 33$ [13], [14], [15], [16]. 


\subsection{WRPLOT View Software Applications}

Aswan and Al Nozha Synop reports wind observations for years of 2006, 2007, 2008 and Marsa Alam wind observations for year 2006 produced by Marsa Alam airport organization (EMAK Company) are processing by WRPLOT View software and produced suitable two types of wind summaries for FAA Airport Design software And Windrose II technique for each case study. WRPLOT View software gives the designer an estimation of the wind resultant vector to help him to find the direction of the runway because the runways should be sets in the direction of prevailing wind. The wind resultant vector for Aswan airport, Al Nozha airport and Marsa Alam airport is near the north direction and has degree of 356, 336 and 336 respectively as shown in figure 5. Figure 6 show the wind rose for Aswan station, Al Nozha station and Marsa Alam station produced by Egyptian meteorological organization for period of 40 years.

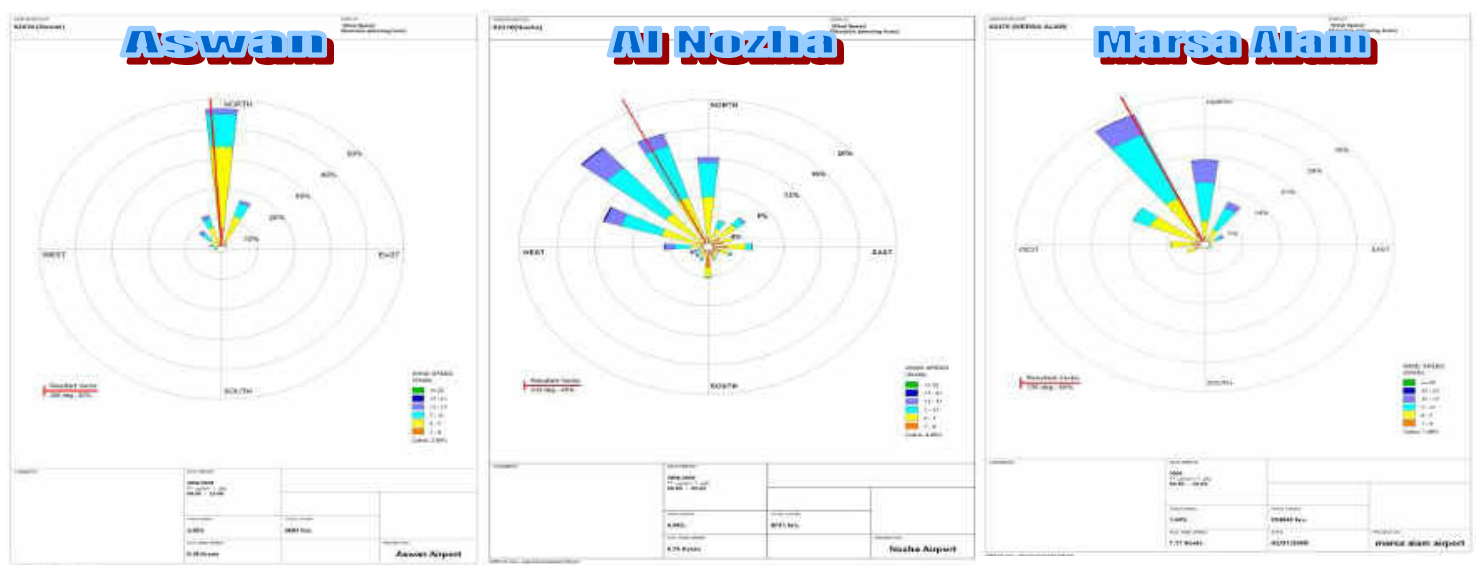

Figure 5. Aswan airport, Al Nozha airport and Marsa Alam airport wind rose produced by WRPLOT View software.
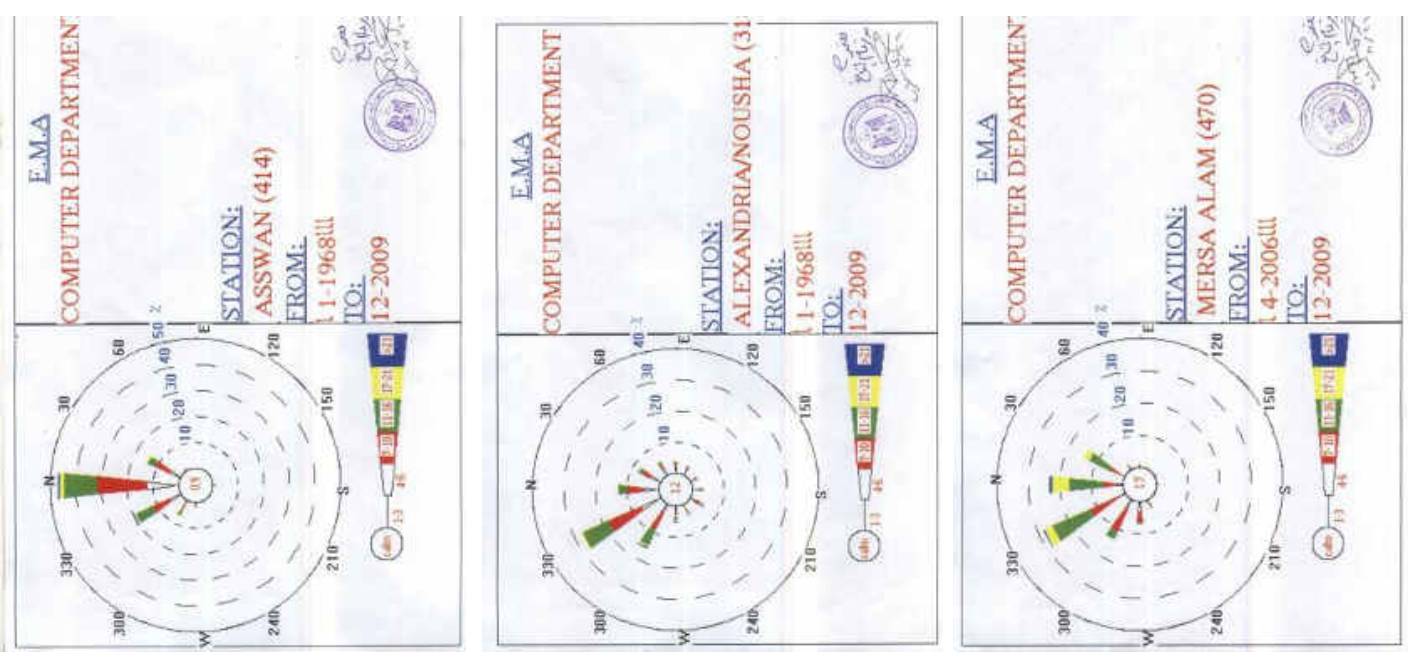

Figure 6. The wind rose for station, Al Nozha station and Marsa Alam station produced by Egyptian meteorological organization. 


\subsection{Windrose II Applications}

The manual wind rose II technique is used to estimate the optimum runway orientation for each case study by analyzing wind summaries. The first wind summaries produced by processing the raw wind data of Aswan and Al Nozha Synop reports and the raw wind data produced by Marsa Alam airport organization (EMAK Company) with WRPLOT View software. The second wind summaries produced by the Egyptian meteorological organization. The percentage of time and the direction of wind are marked in the proper sector of wind rose diagram. The transparent template designed for permissible cross wind 10 Knots is rotated about the center of the wind rose diagram until the direction of the center line yield the maximum percentage of wind coverage between the outer parallel lines. In figure 7 it is found that the best runway orientation for the wind summary produced by processing the raw wind data of Aswan Synop reports with WRPLOT View software is $175 / 355$ and computed wind coverage is $97.63 \%$. In Figure 8 it is found that the best runway orientation for the Aswan wind summary produced by the Egyptian meteorological organization is $175 / 355$ and computed wind coverage is $95.2 \%$. In Figure 9 it is found that the best runway orientation for the wind summary produced by processing the raw wind data of $\mathrm{Al}$ Nozha Synop reports with the WRPLOT View software is 145/325 and computed wind coverage is $95.3 \%$. In Figure 10 it is found that the best runway orientation for the $\mathrm{Al}$ Nozha wind summary produced by the Egyptian meteorological organization is $145 / 325$ and computed wind coverage is $94.1 \%$. In Figure 11 it is found that the best runway orientation for the wind summary produced by processing the raw wind data produced by Marsa Alam airport organization (EMAK Company) with the WRPLOT View software is $160 / 340$ and computed wind coverage is $99.8 \%$. In Figure 12 it is found that the best runway orientation for the wind summary produced by the Egyptian meteorological organization is $170 / 350$ and computed wind coverage is $95.04 \%$.

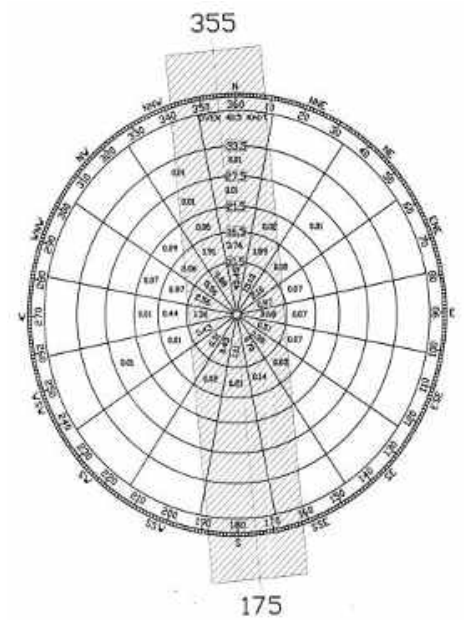

Figure 7. Estimated orientation and wind coverage for Aswan airport runway by using WRPLOT View software wind summary.

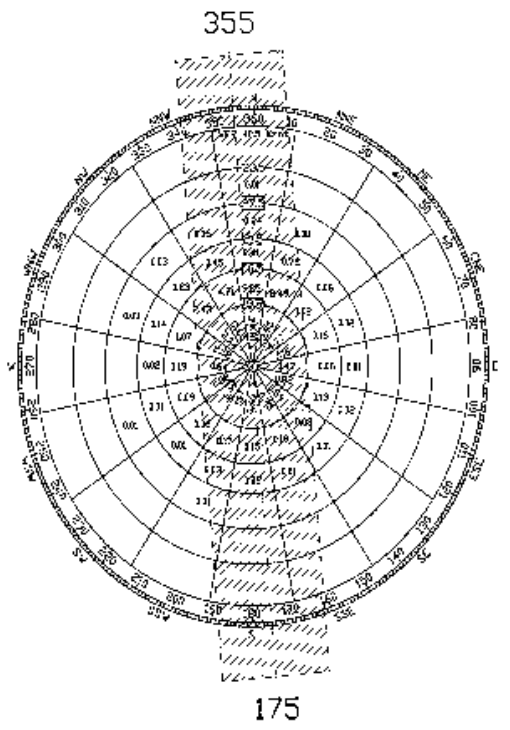

Figure 8. Estimated orientation and wind coverage for Aswan airport runway by using Egyptian meteorological organization wind summary. 


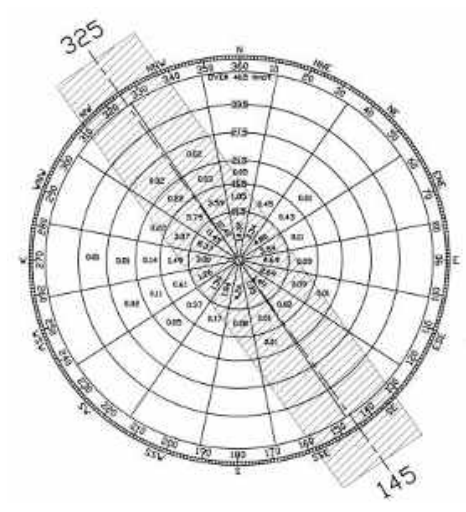

Figure 9. Estimated orientation and Wind coverage for Al Nozha airport runway by using WRPLOT View software wind summary.

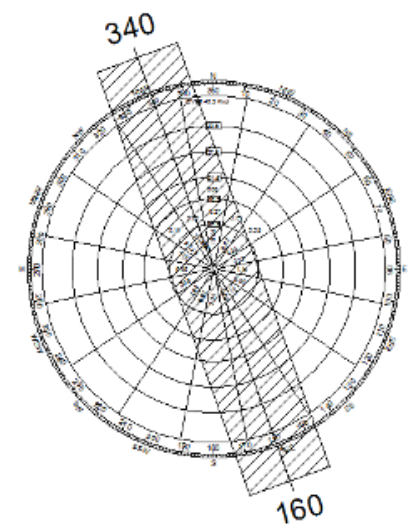

Figure 11. Estimated orientation and wind coverage for Marsa Alam airport runway by using WRPLOT View software wind summary.

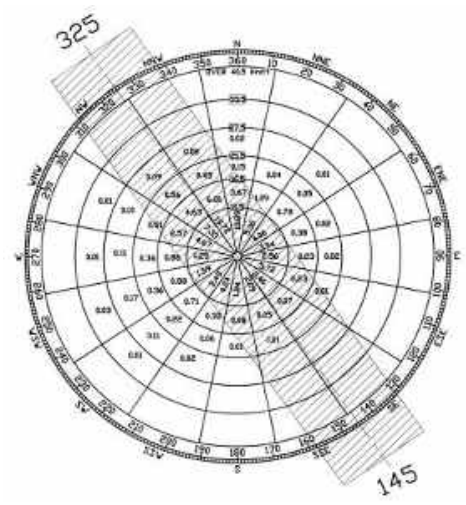

Figure 10. Estimated orientation and wind coverage for Al Nozha airport runway by using Egyptian meteorological organization wind summary.

$$
355
$$

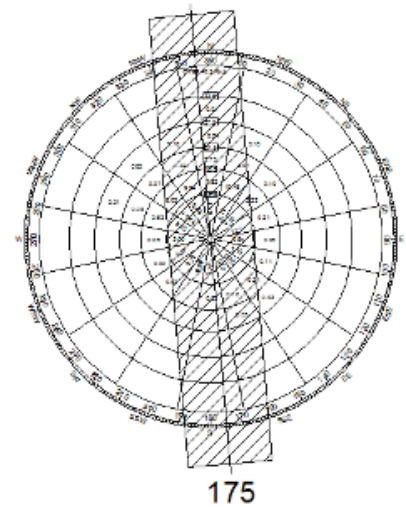

Figure 12. Estimated orientation and wind coverage for Marsa Alam airport runway by using Egyptian meteorological organization wind summary.

\subsection{FAA Airport design Software Application}

In order to find the optimum runway orientation for each case study by using the FAA Airport Design software, the data of wind summary that produced by analysis raw wind data of Aswan and Al Nozha Synop reports and the raw wind data produced by Marsa Alam airport organization (EMAK Company) with WRPLOT View software and the available cross wind component will be filled in the FAA Airport Design software wind analysis table. The runway orientation degree will be filled with different degrees to obtain the maximum wind coverage. After many tries of runway orientation degree for Aswan international airport it is found that the best runway orientation is $174 / 354$, wind coverage is $98.2 \%$ and runway designation is $17 / 35$. After many tries of runway orientation degrees for Al Nozha international airport it is found that the best runway orientation is $146 / 326$, wind coverage is $96.04 \%$ and runway designation is $15 / 33$. After many tries of runway orientation degrees for Marsa Alam 
international airport it is found that the best runway orientation is $156 / 336$, wind coverage is $99.72 \%$ and runway designation is $16 / 34$.

\subsection{WindRose PRO Software Application}

In order to find the optimum runway orientation for each case study by using the WindRose PRO software, raw wind data provided by Aswan and Al Nozha Synop reports and the raw wind data produced by Marsa Alam airport organization (EMAK Company) will be saved in suitable excel format for WindRose PRO software. This excel format will be loaded in WindRose PRO software. The design crosswind component and angular step of runway orientation will be specified. After reviewing the output data with KML files data for Aswan international airport it is found that best runway orientation is $175 / 355$, wind coverage is $97.89 \%$ and runway designation is $18 / 36$ as shown in figure 13. After reviewing the output data with KML file data for Al Nozha international airport it is found that best runway orientation is $145 / 325$, wind coverage is $96.311 \%$ and runway designation is $15 / 33$ as shown in figure 14. After reviewing the output data with KML file data for Marsa Alam international airport it is found that best runway orientation is $155 / 335$, wind coverage is $95.821 \%$ and runway designation is $16 / 34$ as shown in figure 15 .
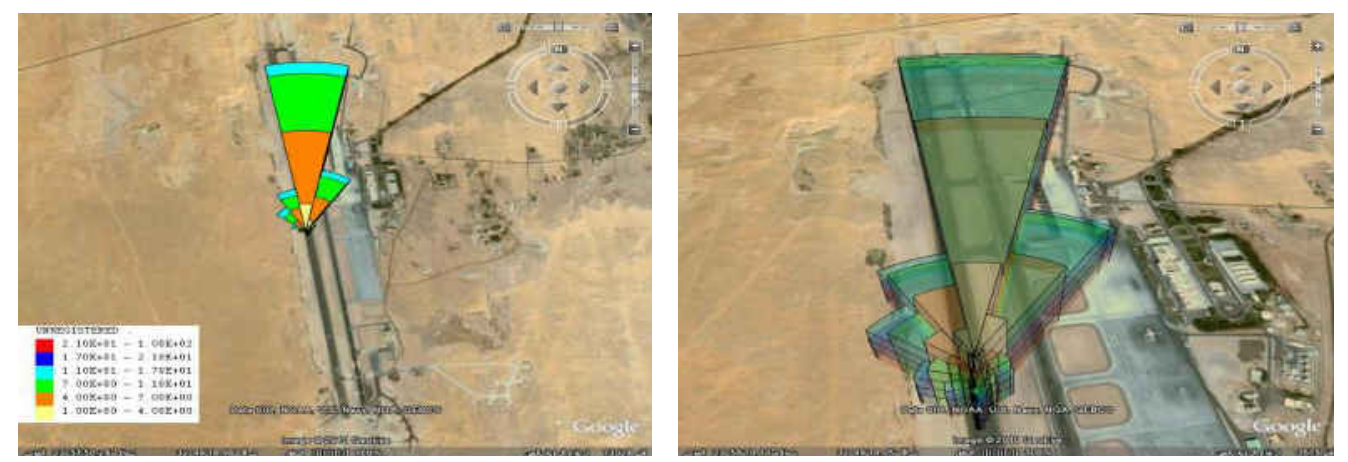

Figure 13. Print out of Aswan airport KML file produced with WindRose PRO.
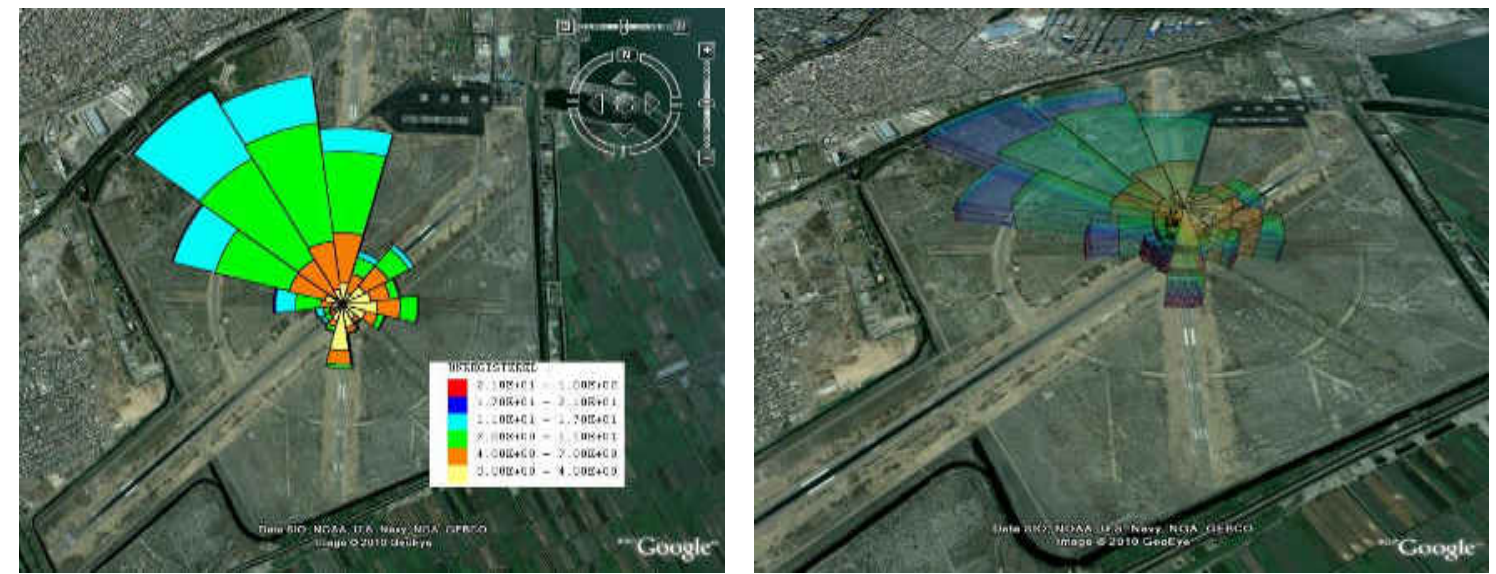

Figure 14. Print out of Al Nozha airport KML file produced with Wind Rose PRO. 

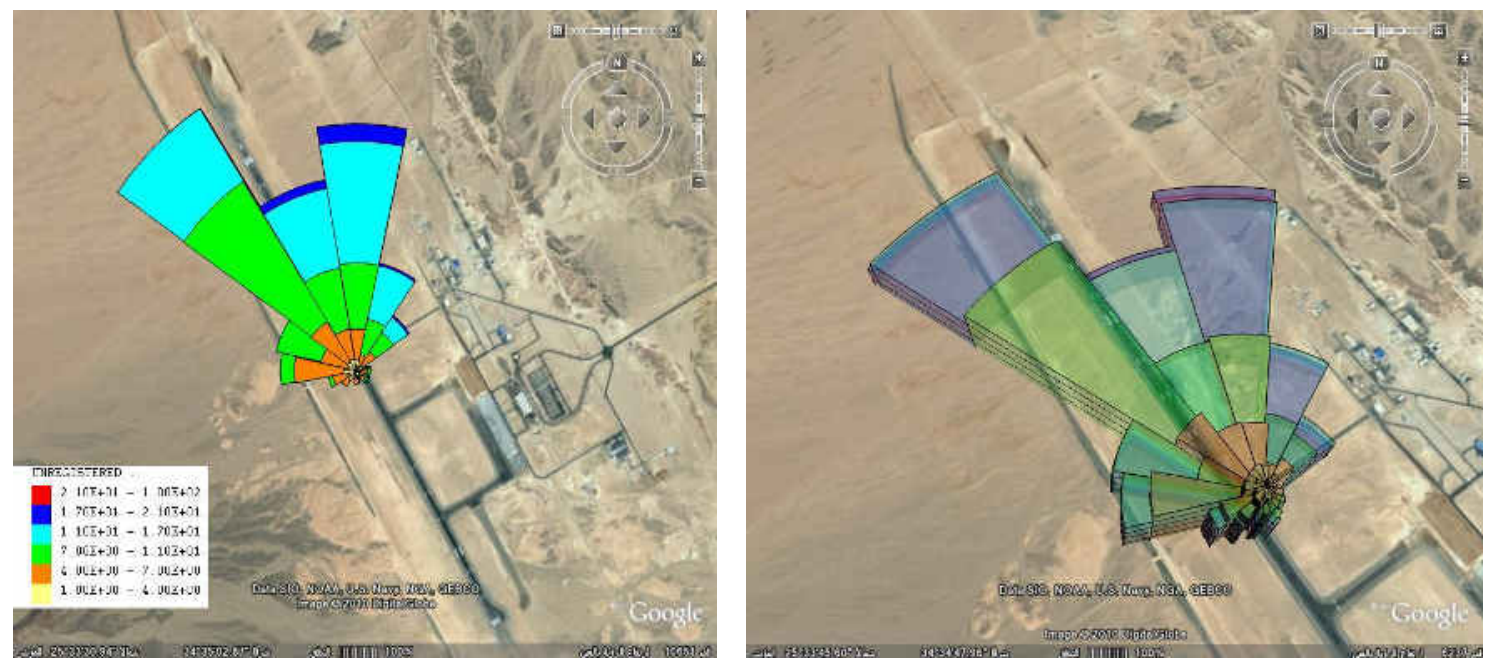

Figure 15. Print out of Marsa Alam airport KML file produced with Wind Rose PRO.

\section{CHECKING OF SEVERAL TECHNIQUES AND SOFTWARE PROGRAMS ACCURACY:}

\subsection{Checking of Synop reports, Marsa Alam airport organization wind data and WRPLOT View program accuracy}

To check the accuracy of Synop reports and WRPLOT View program a comparison must be made between the results of windrose II technique by using wind summary that produced by analyzing raw wind data of Synop reports with WRPLOT View program and The wind summary that produced by the Egyptian meteorological organization as shown in table 1 and table 2 . After these comparisons it was clearly that the accuracy of raw wind data of Synop reports is excellent and WRPLOT View program are valid and capable of analyzing wind data to produce suitable wind summaries for selecting the optimum runway orientation. And the small differences between wind summaries due to Synop reports and Egyptian meteorological organization wind summaries in terms of wind coverage results are mainly due to the inconsistency in the windrose II technique and for large difference in time range between raw wind data of Synop reports and those of Egyptian meteorological organization.

Table 1. Checking accuracy of Synop reports and WRPLOT View program in terms of runway orientation.

\begin{tabular}{|c|c|c|}
\hline case study & $\begin{array}{c}\text { Wind rose II application optimum } \\
\text { runway orientation by using wind } \\
\text { summary produced by Egyptian } \\
\text { meteorological organization }\end{array}$ & $\begin{array}{c}\text { Windrose II application optimum runway } \\
\text { orientation by using wind summary that } \\
\text { produced by analyzing raw wind data of } \\
\text { Synop reports with WRPLOT View } \\
\text { program }\end{array}$ \\
\hline Aswan & $175 / 355$ & $175 / 355$ \\
\hline Al Nozha & $145 / 325$ & $145 / 325$ \\
\hline
\end{tabular}


Table 2. Checking accuracy of Synop reports and WRPLOT View program in terms of wind coverage.

\begin{tabular}{|c|c|c|c|c|}
\hline $\begin{array}{c}\text { case } \\
\text { study }\end{array}$ & $\begin{array}{c}\text { runway } \\
\text { orientation }\end{array}$ & $\begin{array}{c}\text { Wind rose II application } \\
\text { wind coverage orientation by } \\
\text { using wind summary } \\
\text { produced by Egyptian } \\
\text { meteorological organization }\end{array}$ & $\begin{array}{c}\text { Wind rose II application } \\
\text { wind coverage by using } \\
\text { wind summary that } \\
\text { produced by analyzing } \\
\text { raw wind data of Synop } \\
\text { reports with WRPLOT } \\
\text { View program }\end{array}$ & deference \\
\hline Aswan & $175 / 355$ & $95.2 \%$ & $97.63 \%$ & $2.43 \%$ \\
\hline Al Nozha & $145 / 325$ & $94.1 \%$ & $95.3 \%$ & $1.2 \%$ \\
\hline
\end{tabular}

To check the accuracy of raw wind data of Marsa Alam airport organization we must make comparison between the results of windrose II technique by using wind summary that was produced by analyzing raw wind data of Marsa Alam airport organization with WRPLOT View program and Marsa Alam wind summary that produced by the Egyptian meteorological organization as shown in table 3. After these comparisons it was clear that the accuracy of raw wind data of Marsa Alam airport organization is excellent and the difference between its best runway orientation result comparing with windrose II technique is mainly due to large distance between the location of Marsa Alam international airport and the location of Marsa Alam city (location of local metrological station) and large difference in time range between raw wind data of Marsa Alam airport organization and those of Egyptian meteorological organization

Table 3. Checking accuracy of raw wind data of Marsa Alam airport organization in terms of runway orientation.

\begin{tabular}{|c|c|c|}
\hline case study & $\begin{array}{c}\text { Wind rose II applications optimum } \\
\text { runway orientation by using wind } \\
\text { summary produced by Egyptian } \\
\text { meteorological organization }\end{array}$ & $\begin{array}{c}\text { Wind rose II applications optimum } \\
\text { runway orientation by using wind } \\
\text { summary that produced by analyzing } \\
\text { raw wind data of Marsa Alam airport } \\
\text { organization with WRPLOT View } \\
\text { program }\end{array}$ \\
\hline Marsa Alam & with wind coverage of $95.04 \%$ & $\begin{array}{c}160 / 340 \\
\text { with wind coverage of } 99.8 \%\end{array}$ \\
\hline
\end{tabular}

\subsection{Checking of FAA Airport design program and Wind Rose PRO program accuracy}

To Check programs accuracy of FAA Airport design program and Wind Rose PRO program a comparison must made between each program wind coverage result and wind rose II technique wind coverage result for the same runway orientation (see table $4 \&$ table 5).And we must make comparison between each program best runway orientation and that due to application of wind rose II technique in terms of wind coverage (see table 6). After these comparisons for FAA Airport design program it was clearly that the FAA Airport design program is valid and capable of analyzing wind data to selecting the optimum runway orientation and the small differences between its 
wind coverage results and windrose II technique are mainly due to the inconsistency in the windrose II technique. After these comparisons for Windrose PRO program it was clearly that the Windrose PRO program is valid and capable of analyzing wind data to selecting the optimum runway orientation but its accuracy less than the accuracy of FAA Airport design program because it is capable of examining the runway orientation only every 5 angular degree but FAA Airport Design capable of examining the runway orientation at any angular degree. While FAA Airport Design studies the effect of runway orientations on wind coverage will keeping other parameters fixed (Number of runways, Runway orientation, Maximum allowable crosswind component and Maximum allowable tailwind component) but Windrose PRO program studies the effect of runway orientations on all this parameters except Maximum allowable crosswind component that will make some turbulence in its wind coverage results see figure 16. The small differences between those wind coverage results are mainly due to the inconsistency in the windrose II technique.

Table 4. FAA Airport design program and windrose II technique results comparison and differences for the same runway orientation.

\begin{tabular}{|c|c|c|c|c|}
\hline Case Study & $\begin{array}{c}\text { Runway } \\
\text { Orientation }\end{array}$ & $\begin{array}{c}\text { FAA Airport Design } \\
\text { Software } \\
\text { Wind Coverage }\end{array}$ & $\begin{array}{c}\text { Wind rose II } \\
\text { applications } \\
\text { Wind Coverage }\end{array}$ & Difference \\
\hline Aswan & $175 / 355$ & $98.10 \%$ & $97.63 \%$ & $0.47 \%$ \\
\hline Al Nozha & $145 / 325$ & $96.03 \%$ & $95.30 \%$ & $0.73 \%$ \\
\hline Marsa Alam & $155 / 335$ & $99.78 \%$ & $99.80 \%$ & $-0.02 \%$ \\
\hline
\end{tabular}

Table 5. Windrose PRO program and Windrose II technique results comparison and differences for the same runway orientation.

\begin{tabular}{|c|c|c|c|c|}
\hline Case Study & $\begin{array}{c}\text { Runway } \\
\text { Orientation }\end{array}$ & $\begin{array}{c}\text { Wind Rose PRO } \\
\text { Software } \\
\text { Wind Coverage }\end{array}$ & $\begin{array}{c}\text { Wind rose II } \\
\text { applications } \\
\text { Wind Coverage }\end{array}$ & Difference \\
\hline Aswan & $175 / 355$ & 97.89 & $97.63 \%$ & $0.26 \%$ \\
\hline Al Nozha & $145 / 325$ & 96.311 & $95.30 \%$ & $1.01 \%$ \\
\hline Marsa Alam & $155 / 335$ & 97.222 & $99.80 \%$ & -2.58 \\
\hline
\end{tabular}

Table 6. Comparison between each program best runway orientation in terms of wind coverage and best runway orientation of wind rose II technique.

\begin{tabular}{|l|l|l|l|}
\hline Case Study & $\begin{array}{c}\text { FAA Airport Design } \\
\text { Software } \\
\text { Runway Orientation }\end{array}$ & $\begin{array}{c}\text { Wind Rose PRO } \\
\text { Software } \\
\text { Runway Orientation }\end{array}$ & $\begin{array}{c}\text { Wind rose II } \\
\text { applications } \\
\text { Runway Orientation }\end{array}$ \\
\hline Aswan & $174 / 354$ & $160 / 340$ & $175 / 355$ \\
\hline Al Nozha & $146 / 326$ & $135 / 315$ & $145 / 325$ \\
\hline Marsa Alam & $156 / 336$ & $170 / 350$ & $160 / 340$ \\
\hline
\end{tabular}



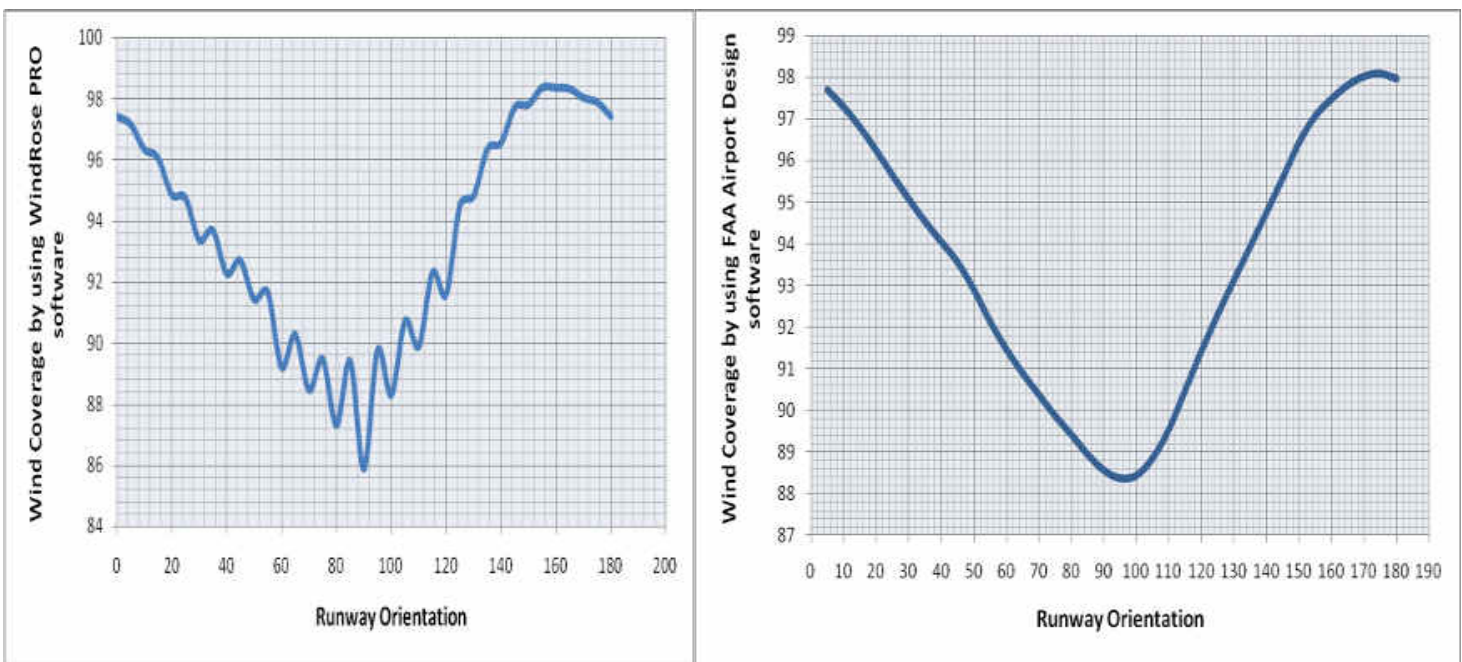

Figure 16. Show difference between FAA Airport Design wind coverage results and WindRose PRO wind coverage results For Aswan international airport.

\section{OPTIMUM RUNWAY ORIENTATION}

The important factors that affect the numbers and orientation of the runways are amount of crosswind component and the corresponding amount of wind coverage. In all local cases studies one optimum oriented runway will obtain the minimum $95 \%$ wind coverage stated by ICAO organization as follows:

Aswan international airport: one runway can provide wind coverage equal or more than $95 \%$ in the range between $30 / 210$ to $145 / 325$. The existing runway which is $170.88 / 350.88$ provides $98.07 \%$ wind coverage and its designation is $17 / 35$. While the optimum runway orientation is $174 / 354$ provides $98.2 \%$ wind coverage and its designation is $17 / 35$ as shown in figure 17.

Al Nozha international airport: one runway can provide wind coverage equal or more than $95 \%$ in the range between $165 / 345$ to $125 / 305$. This airport has two existing runways. The first existing runway orientation is $45.06 / 225.07$ provides and $84.7 \%$ wind coverage and its designation is $40 / 22$. The second existing runway orientation is $179.99 / 359.99$ provides $93.27 \%$ wind coverage and its designation is $18 / 36$. While the optimum runway orientation is $146 / 326$ and provides $96.04 \%$ wind coverage and its designation is $15 / 33$. as shown in figure 17 .

Marsa Alam international airport: one runway can provide wind coverage equal or more than $95 \%$ for any direction. The existing runway which is $149.75 / 329.76$ provides $99.65 \%$ wind coverage and its designation is $15 / 33$. While the optimum runway orientation is $156 / 336$ and provides $99.72 \%$ wind coverage and its designation is $16 / 34$. as shown in figure 17 . 

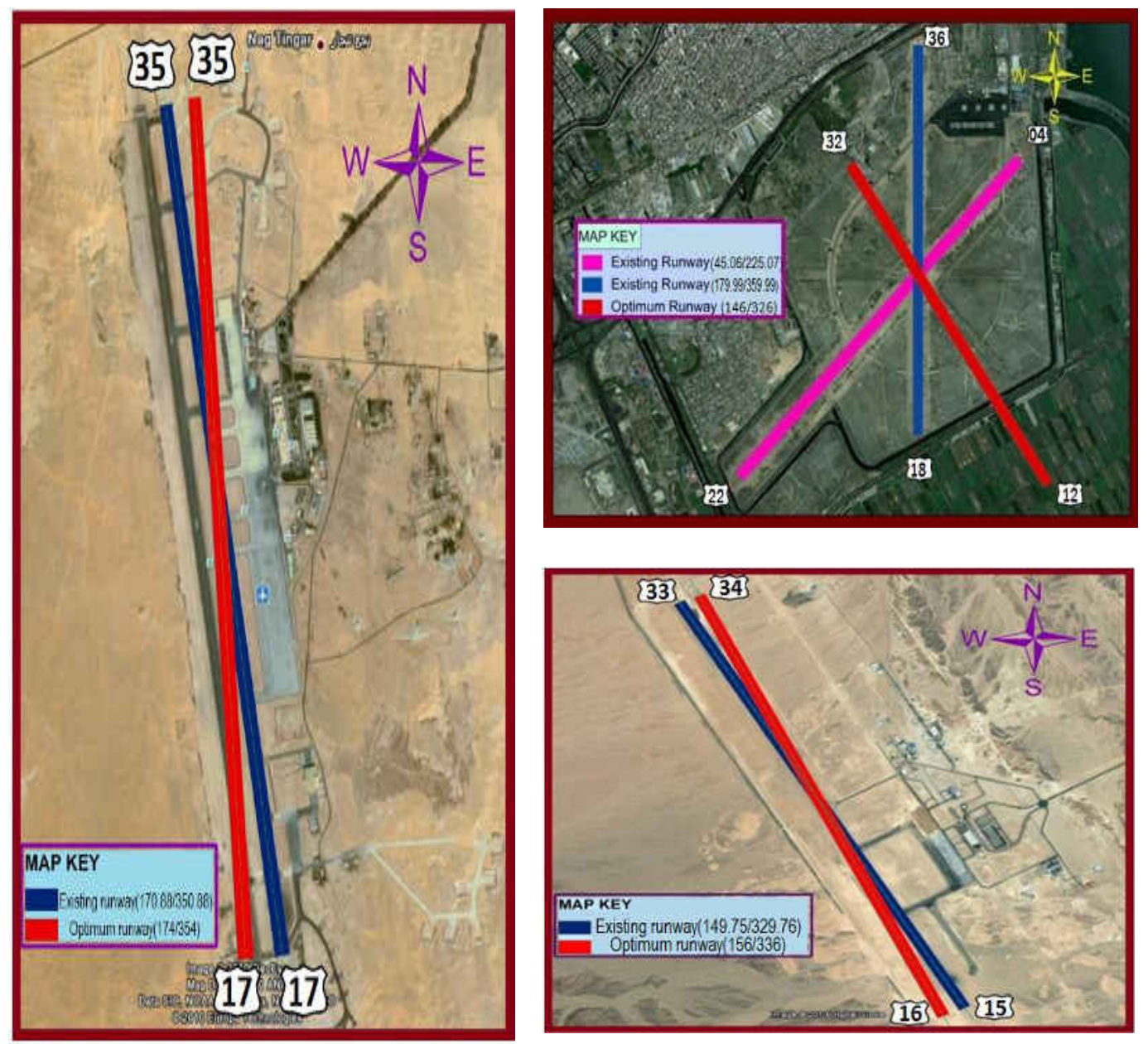

Figure 17. Maps show the difference between existing runway orientation and optimum runway orientation for Aswan international airport, Al Nozha international airport and Marsa Alam international airport.

\section{PARAMETRIC ANALYSIS}

In order to conduct parametric analysis each effective parameter must be applied in each case study with a uniform of value. Changes of the results due to the relation between these parameters which are to be studied. FAA Airport design software used to run this analysis because it allows the designer to keeping the other parameters fixed while changing one of them and the accuracy of FAA Airport design software higher than the accuracy of Windrose PRO software to run this study. The parameters to be considered are: Number of runways, Runway orientation, Maximum allowable crosswind component and Maximum allowable tailwind component. In my cases studies the parameter of numbers of runways will not be considered due to wind pattern of each case study one good oriented runway will obtain at least $95 \%$ wind coverage. 


\subsection{Runway Orientation}

The effect of runway orientation can be shown in each case study by keeping other parameters fixed while changing runway orientation to draw a relation between runway orientation and wind coverage. In this study all these parameters are considered for all airports as follows; Wind data as provided by Synop reports or airport organization, Maximum allowable crosswind component $=10$ Knots, Maximum allowable tailwind component $=60$ Knots. The resulting relations are shown in Figure 18 for Aswan international airport, Al Nozha international airport and Marsa Alam international airport.
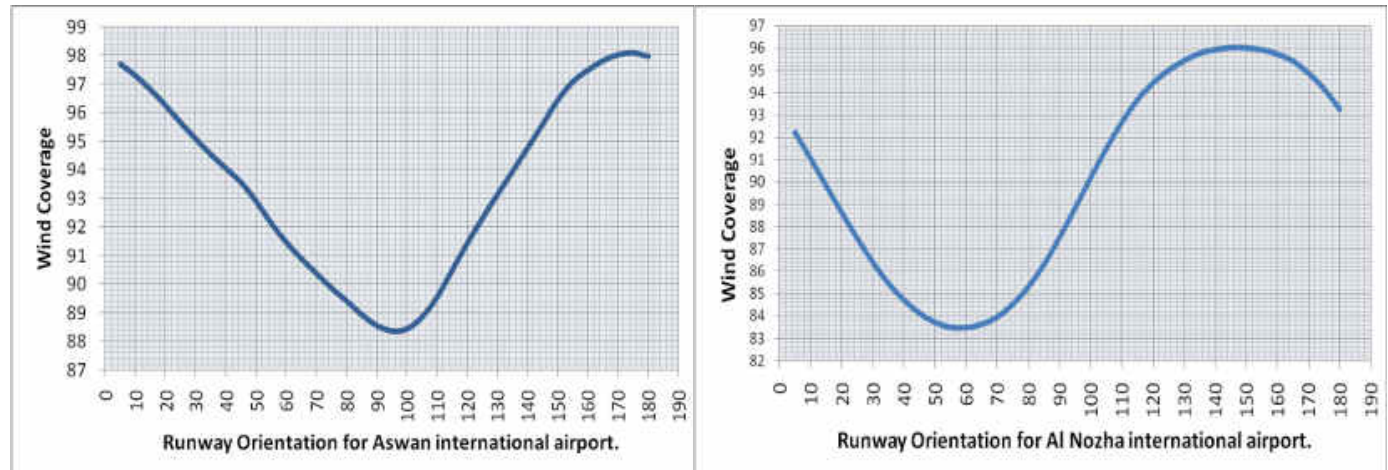

Figure 18. Wind coverage Versus Runway orientation for Aswan international airport Al Nozha international airport and Marsa Alam international airport.

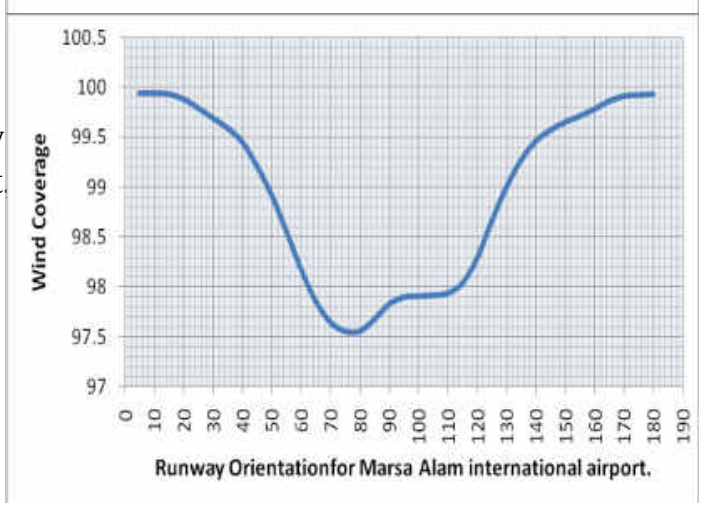

\subsection{Maximum Allowable Crosswind Component.}

This factor depends on the classification of the airport and the type of aircrafts. The effect of maximum allowable crosswind component can be found by changing its value while keeping others parameter fixed. The value must range from 10 Knots to $20 \mathrm{Knots}$ which represent the minimum and maximum allowable crosswind component stated by most of the aviation authorities. In this study all these parameters are considered for all airports as follows; Wind data as provided by Synop reports or airport organization, Runway orientation 90/270 and Maximum allowable tailwind component $=60$ Knots. The resulting relations are shown in Figure 19 for Aswan international airport, Al Nozha international airport and Marsa Alam international airport. In all cases studies it is clear that single runway is enough to provide the minimum wind coverage of $95 \%$ but with different sensitivity in each case. 

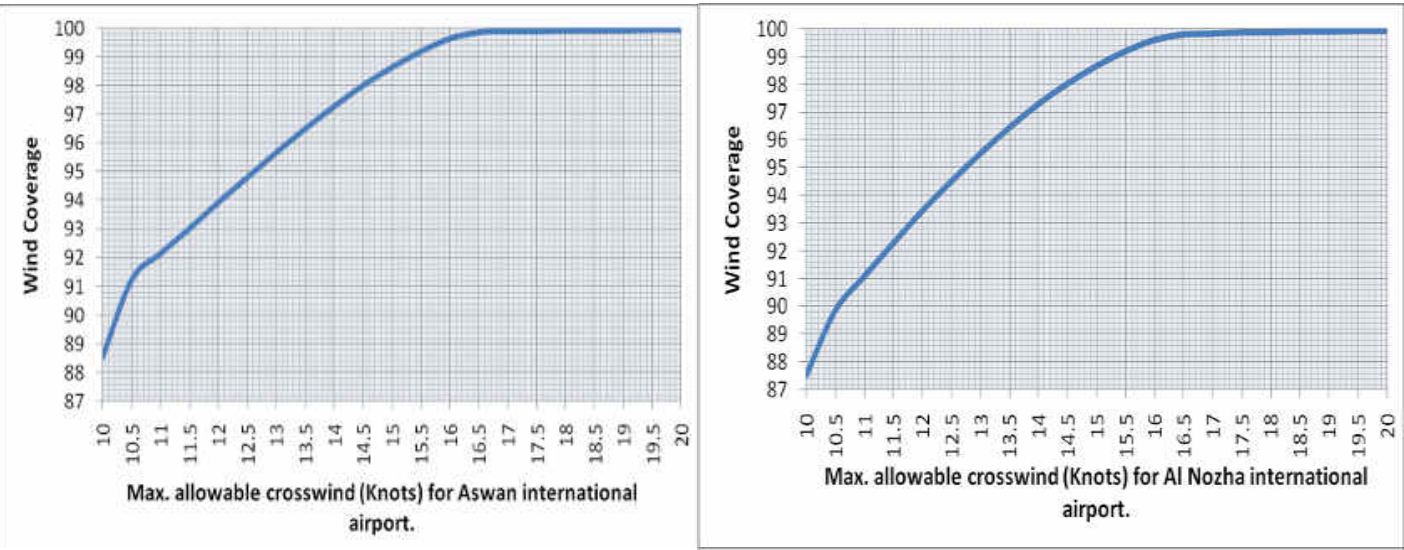

Figure 19. Wind coverage Versus Max. allowable crosswind for Aswan international airport, Al Nozha international airport and

Marsa Alam international airport.

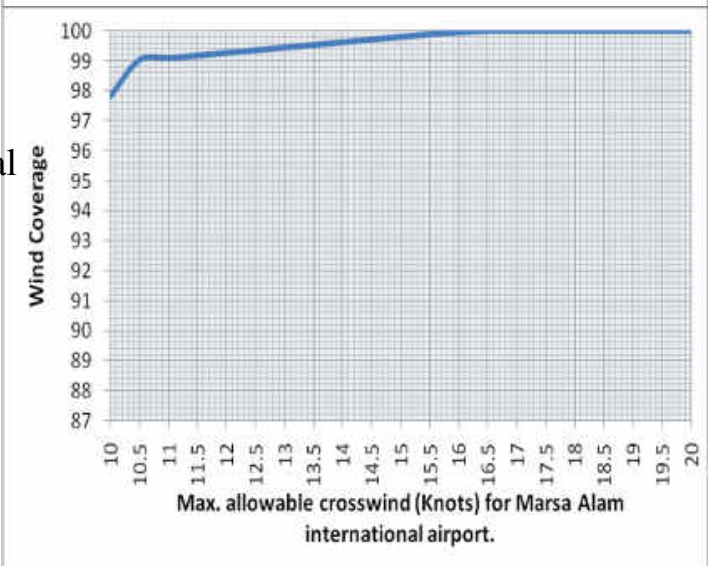

\subsection{Maximum Allowable Tailwind Component.}

The effect of maximum allowable tailwind component can be found by changing its value while keeping others parameter fixed. The value must rang from 0Knots to 20Knots. In this study all these parameters are considered for all airports as follows; Wind data as provided by Synop reports or airport organization, Runway orientation 90/270 and Maximum allowable crosswind component $=10$ Knots. The resulting relations are shown in Figure 20 for Aswan international airport, Al Nozha international airport and Marsa Alam international airport. This fingers show that local cases studies are sensitive to the tail wind components between 0Knots and 15Knots while in 20Knots and more this effect is eliminated.

\section{CONCLUSIONS}

The conclusions which can be drawn from this study are summarized as follows:

1- The wind data of Ogimet website Synop reports are matched with Egyptian Meteorological organization and capable to study Egyptian wind pattern.

2- WRPLOT View software program is essential to analyze raw wind observations to estimate wind resultant vector, draw windrose and to produce wind tables suitable to analyze wind data. 3- FAA airport design software program is capable of analyzing local wind data to find the optimum runway orientation. 

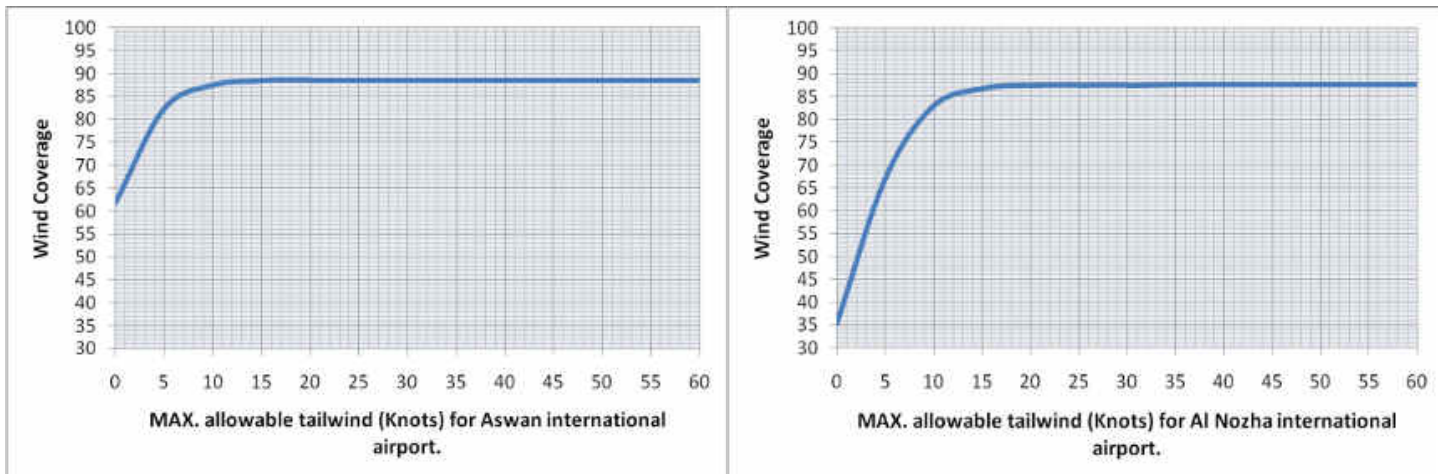

Figure 20. Wind coverage Versus Max allowable tailwind for Aswan international airport, Al Nozha international airport and

Marsa Alam international airport.

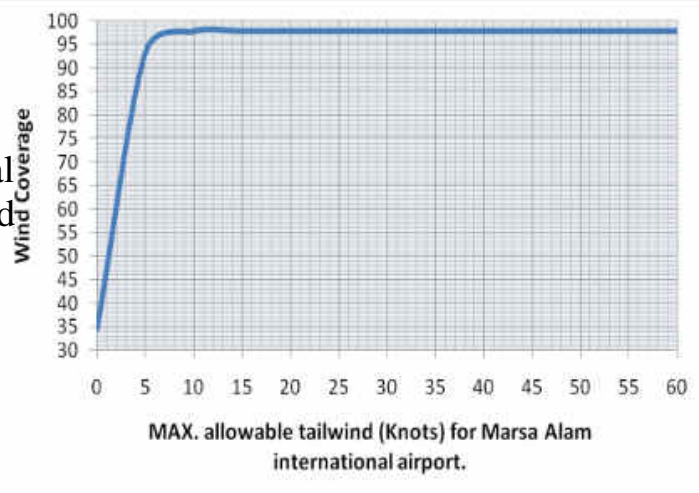

3- WindRose PRO software program is capable of analyzing local wind data to find the optimum runway orientation but its results have some non uniform change because it takes many variables during analysis. Otherwise the present considers only the effect of wind coverage on runway direction while keeping other parameters fixed.

4- Most of Egyptian airports runways are oriented to the direction of prevailing wind that gained from Egyptian Meteorological organization windrose pattern and they should be oriented by use of any adequate technique of the recent studies.

5- The runways in Marsa Alam international airport and Aswan international airport have acceptable orientation but not the optimum.

6- Al Nozha international airport has two runways with deferent non acceptable orientations but the optimum solution is one oriented runway.

7- The effect of maximum allowable crosswind component has highest identical impact on Aswan international airport and Al Nozha international airport while Marsa Alam international airport has less effect by the variation of this component.

8- The effect of maximum allowable tailwind component has identical impact on the three case studies of Aswan international airport, Al Nozha international airport and Marsa Alam international airport. 


\section{REFERENCES}

1- Horonjeff R. and Mckelvey F. X. "Planning and Design of Airports" MeGraw-Hill Book company / third edition. New York 1986.

2- Kumar V. and Chandra S. "AIR TRANSPORTATION PLANING AND DESIGN" Galgotia Publications Pvt. Ltd. / First edition. New Delhi 1999.

3- Circular AC 150/5300-13. Appendix 1. AIRPORT DESIGN Advisory. Federal Aviation Administration. U.S. DEPARTMENT OF TRANSPORTATION FEDERAL AVIATION ADMINISTRATION Flight Standards Service. Washington DC 29/9/1989.

4- Antonio A. Trani, Virginia Tech, "Airport Runway Location and Orientation," "http://ebookbrowse.com/runway-orientation-pdf-d76460980"

5- WIKIPEDIA the free "Crosswind" "http://en.wikipedia.org/wiki/Crosswind"

6- G.W.H. van Es, P.J. van der Geest and T. M.H. Nieuwpoort "Safety aspects of aircraft operations in crosswind", National Aerospace Laboratory NLR (Nationaal Lucht- en Ruimtevaartlaboratorium), NLR-TP-2001-217, May 2001.

7- NATIONAL OCEANIC AND ATMOSPHERIC ADMINISTRATION (NOAA) "Synop reports" "http://www.ogimet.com/"

8- WIKIPEDIA the free encyclopedia "Synop reports" "http://en.wikipedia.org/wiki/SYNOP"

9- Federal Meteorological Handbook (FMH), LAND STATION SURFACE SYNOPTIC CODE FM 12-IX SYNOP, "Synop reports format" "http://atmo.tamu.edu/class/atmo251/LandSynopticCode.pdf"

10- Circular AC 150/5300-13. Appendix 11. AIRPORT DESIGN Advisory. Federal Aviation Administration. U.S. DEPARTMENT OF TRANSPORTATION FEDERAL AVIATION ADMINISTRATION Flight Standards Service. Washington DC 29/9/1989.

11- Enviroware company "WindRose PRO software" "http://www.enviroware.com/windrose.htm"

12- Lakes Environmental Company "WRPLOT View software" "http://www.weblakes.com/products/wrplot/index.html"

13- Ministry of civil aviation, "Aeronautical Information Publication" AIP A.R.E, Cairo, 13 JAN 2011.

14- ICAO and FAA, Detailed aeronautical search engine, WORLD AERO DATA "Aswan airport" "http://worldaerodata.com/wad.cgi?id=EG90656\&sch=HESN"

15- ICAO and FAA, Detailed aeronautical search engine, WORLD AERO DATA "Al Nozha airport" "http://worldaerodata.com/wad.cgi?id=EG62850\&sch=HEAX"

16- ICAO and FAA, Detailed aeronautical search engine, WORLD AERO DATA "Marsa Alam airport" "http://worldaerodata.com/wad.cgi?id=EG00005\&sch=HEMA" 


\section{بحث في اختيار الاتجاه الأمثل لمدارج المطارات باستدلال المطارات المصرية}

تحديد اتجاه المدرج هو المهمة الحاسمة في تخطيط وتصميم المطارات. تحديد اتجاه المدرج يؤثر على تخطيط باقي مرافق

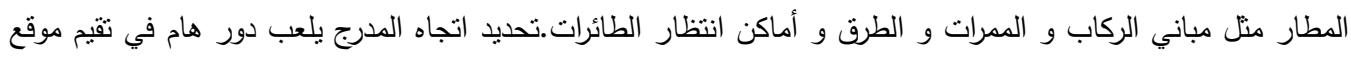

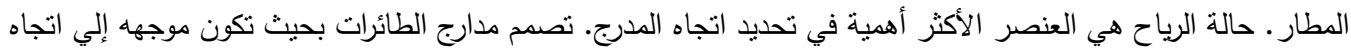
الرياح السائدة. الاتجاه الأمتل للمدارج يمكن إن يحدد عن طريق التحليل الدقيق لقراءات تسجيل (أرصاد) الرياح في المنطقة لمدة 10 سنوات.

في هذه الدراسة نم تحليل أرصاد الرياح بواسطة الطريقة التقليدية و برامج الحاسوب للتحقق من دقة البرامج المستخدمة عن

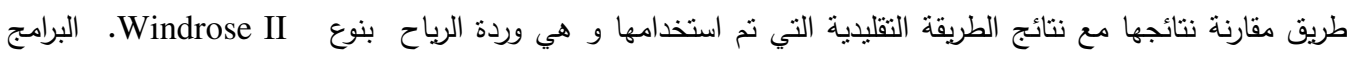

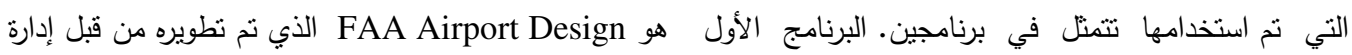

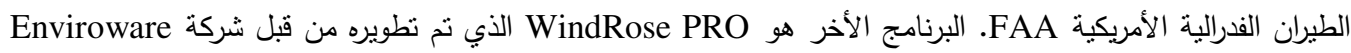

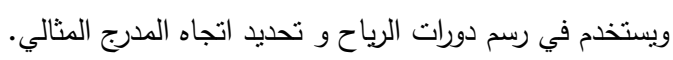

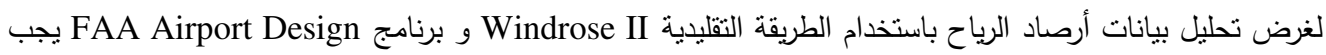

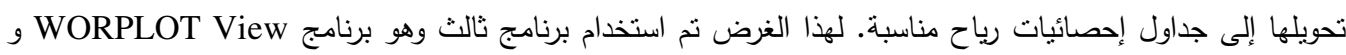
يستخدم في عمل إحصائيات الرباح ورسم وردات الرياح. في هذه الدراسة تم استخدام ثلاث حالات دراسية لتحديد الاتجاه الأمثل للمدرج وهي مطار أسوان الدولي و مطار النزهة

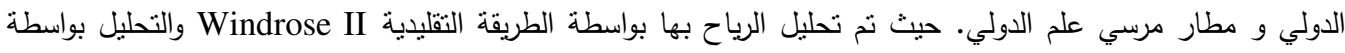
برامج الكومبيوتر (FAA Airport Design, WindRose PRO). بعد مقارنة نتائج تحليل الرياح بواسطة الطريقة التقليدية Windrose II والتحليل بواسطة برامج الكومبيوتر FAA Airport Design وجدت فروق صغيرة بين هذه النتائج تنزاوح بين -0.02\% إلي 0.73 \% إذا برنامج FAA Airport Design يصلح لتحليل الرياح لإيجاد انجاه المدرج المثالي.

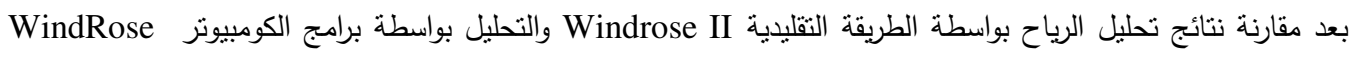

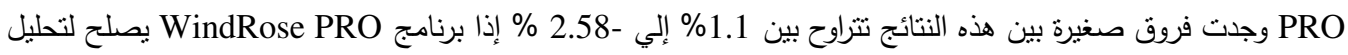

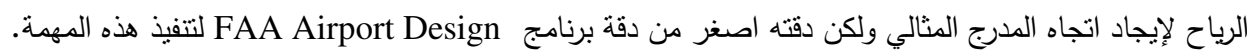

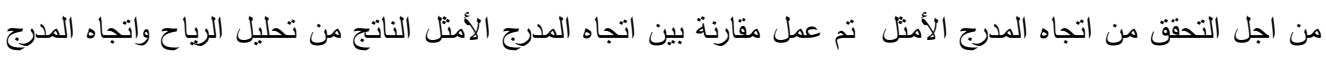

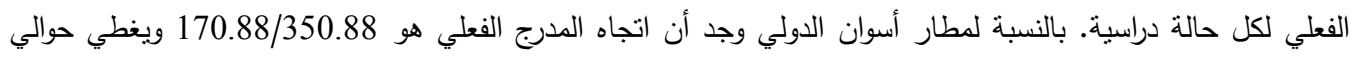

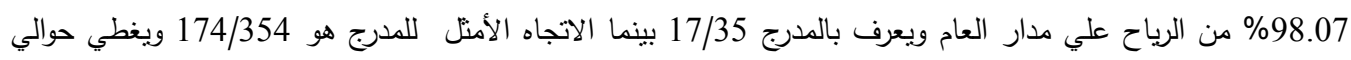
98.2 من الرياح علي مدار العام ويعرف بالمدرج 17/35. بالنسبة لمطار النزهة الدولي يوجد مدرجان الاتجاه الفعلي لهم بلاه

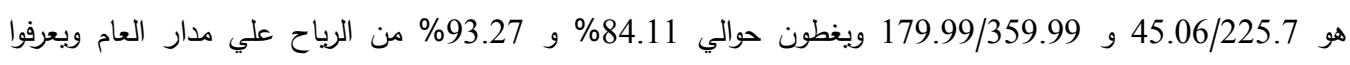

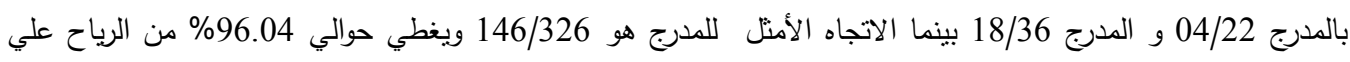
مدار العام ويعرف بالددرج 15/33. بالنسبة لمطار مرسي علم الدولي وجد أن الاتجاه المدرج الفعلي هو

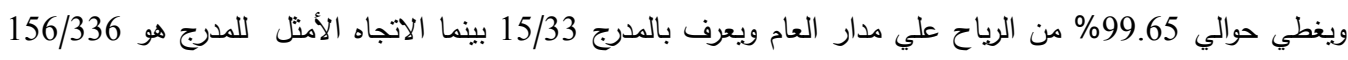

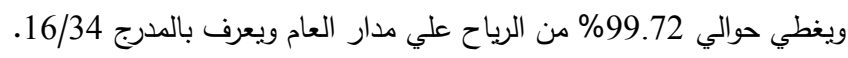

